\title{
РАЗВИТИЕ ЛИЧНОСТИ
}

УДК 378:124

DOI 10.23951/1609-624X-2018-5-166-174

\section{РАЗВИТИЕ ТВОРЧЕСКОГО ПОТЕНЦИАЛА ЛИЧНОСТИ СТУДЕНТОВ В ПРОЦЕССЕ ОБУЧЕНИЯ}

\section{В. И. Степанов}

Алтайский экономико-юридический институт, Барнаул

\begin{abstract}
Отражены идеи развития творческого потенциала личности студентов в процессе профессиональной их подготовки. В процессе развития творческого потенциала личности студентов выделены этапы в логике основных тенденций. Рассмотрены аспекты развития творческого потенциала личности студентов, выделены педагогические условия его формирования, создания креативной среды, побуждения рефлексивной деятельности, диалогизация образовательного процесса. Проведено анкетирование и тестирование студентов Алтайского государственного технического университета и Алтайского экономико-юридического института. Представлены результаты исследования творческого потенциала личности студентов в процессе обучения в государственных и частных вузах. Данные анкетирования и тестирования позволили сделать вывод, что тип образовательной организации не влияет на удельный вес студентов, обладающих творческим потенциалом. Опрос студентов разных курсов частного института и государственного университета, а также повторный опрос их с небольшими потерями выборки показал, что количество студентов с исследованными критериями творческого потенциала варьирует в пределах 25-35 \%. Всеми необходимыми качествами обладают в обоих образовательных организациях не более 10-12 \% из числа опрошенных. У 50\% опрошенных эти качества выражены незначительно, 20 \% опрошенных студентов вузов ориентированы на нетворческий учебный процесс и профессиональную карьеру, проявляют конформизм. Оснований для вывода о развитии творческого потенциала личности студентов в целом недостаточно, о чем свидетельствуют удельные веса творческих личностей на разных курсах частного института и государственного университета. Причины авторы видят в том, что, во-первых, основа для такого развития закладывается до поступления в высшее учебное заведение, во-вторых, часть обучающихся, обладающих творческим потенциалом, выбывает из вуза по разным причинам: отсутствие финансирования образования, конфликты с преподавателями и др. В частном вузе, несмотря на действие различных обстоятельств, доля студентов, обладающих творческим потенциалом, остается достаточно стабильной, а в государственном вузе действует тенденция снижения числа таких студентов.
\end{abstract}

Ключевые слова: творческий потенциал личности студентов, склонность к риску, сознательный выбор интересных и развивающих личность занятий.

Развитие современного высшего образования акцентирует внимание на подготовке современных специалистов. Эта проблема является актуальной на протяжении длительного времени. Значение высшего образования неуклонно возрастает и требует творческого подхода на практике. Творчеству научить нельзя - необходимо развивать творческий потенциал будущего специалиста в процессе обучения. Изменения затрагивают вузовскую систему образования, которая должна обеспечить хозяйствующие субъекты высококвалифицированными, компетентными специалистами, способными решать задачи цифровой экономики. От них требуются в новых условиях способности применять инновации в практической деятельности, готовность к диалогу и сотрудничеству, информационная и коммуникативная культура, мастерство и высокий творческий потенциал для решения задач.

В свете гуманистической парадигмы высшего образования творческий потенциал личности сту- дентов - ряд свойств и качеств, необходимых для субъективно творческой деятельности в процессе обучения.

Творческий потенциал является многоэлементной структурой, включающей комплекс способностей, личностные качества, эмоционально-волевую сферу личности. Систематизирующим фактором указанных элементов является творческий потенциал личности. Процесс его развития в процессе обучения - это деятельность самих студентов.

Нельзя не согласиться с мнением И. В. Давыдовой, что содержание понятия «творческий потенциал личности» можно рассматривать «как структурное личностно-деятельностное и общественно значимое образование, включающее скрытые (резервные) возможности личности, ее актуализированные (реализованные) способности к творческой деятельности, а также совокупность знаний, умений, навыков, которые обусловливают формирование и развитие профессиональных компетенций 
личности. Развитие творческого потенциала личности студентов обусловлено наличием внутренних (интеллект, творческое мышление, способности, внутренняя мотивация) и внешних (психологический микроклимат в группе в процессе межличностного взаимодействия, подходы в учебном процессе) условий» [1].

В педагогике высшей школы используется «модель специалиста», включающая изложение необходимых ему знаний, умений, качеств. По мнению Л. Д. Медведевой, с появлением ФГОС подготовка специалистов стала ориентироваться на эти требования, а его модель стала дополняться традиционными личностными качествами (ответственностью, общекультурной грамотностью, психическим здоровьем и др.) [2, с. 77].

О. Ю. Малахова полагает, что в настоящее время одной из основных тенденций стало выдвижение на первый план вопросов содействия профессиональному развитию личности, ее становлению и самореализации в процессе вузовской подготовки [3].

Т. В. Мясникова считает, что активность личности, представленная интеллектуальной, субъективной и другими ее видами, способствует развертыванию творческого потенциала [4, с. 614].

Совершенно справедливо, замечает В. И. Андреев, что тенденции развития образования сегодня актуализируют подготовку профессионала, конкурентоспособного в быстро изменяющихся рыночных условиях, творческого, способного к активному самосовершенствованию и саморазвитию, стремящегося к обучению и повышению квалификации, обновлению знаний и компетенций на протяжении всей жизни [5, с. 17].

«Компетенция - это совокупность взаимосвязанных качеств личности (знаний, умений, навыков, способов деятельности), задаваемых по отношению к определенному кругу предметов и процессов и необходимых, чтобы качественно продуктивно действовать по отношению к ним», - пишет А. В. Хуторской [6].

В. И. Блинов, О. Ф. Батрова, Е. Ю. Есенина, А. А. Факторович и др. считают, что кроме знаний, умений и навыков компетенции включают еще мотивационную (ценностно-смысловую) составляющую, характеризующую отношение личности к деятельности. [7]

В. И. Панов определяет огромную важность для полноценного становления личности будущего выпускника технического вуза предметов гуманитарного цикла, способствующих, например:

- правильному развитию творческой активности студентов;

- формированию личностной готовности к использованию технических знаний и умений;
- полноценному развитию коммуникативных и организаторских способностей;

- формированию гуманистических (общечеловеческих) ценностей;

- развитию способности к непрерывному образованию в течение всей жизни и переучиванию в случае необходимости [8, с. 35].

Важнейшим препятствием для индивидуализации высшего образования выступает остающаяся в неприкосновенности традиционная поточно-групповая форма организации учебного процесса, что, по словам Б. А. Сазонова, «является индикатором серьезного технологического отставания российских университетов на фоне развития мирового высшего образования» [9, с. 13].

С. И. Поздеева и А. В. Обсков правильно подчеркивают, что если основное предназначение профессиональных стандартов - развитие производства и они построены на основе функционального подхода, то основное предназначение образовательных стандартов - развитие личности будущего работника [10, с. 119].

Эмпирическое измерение динамики творческих качеств возможно различными методами. Наиболее целесообразными из них авторы считают анкетирование, тестирование, а также экспертную оценку преподавателей.

Тема творческого потенциала личности студентов весьма деликатна и требует гарантий анонимности, которые не обеспечивают биографический метод, эксперимент, опрос, включенное наблюдение и другие. Задача выявления специфики его в частном вузе не может быть решена без сравнения с результатами исследования контрольных групп студентов государственного университета по такой же выборке.

Метод анкетного опроса показался недостаточным, так как он акцентирует субъективное мнение студентов о самих себе и организации учебного процесса.

Одновременно с анкетированием проводилось тестирование.

Для проведения исследования были выбраны два вуза города Барнаула. Первый - частный вуз, в котором работают авторы, - Алтайский экономикоюридический институт (АЭЮИ). В выборку попали 84 студента первого курса, 77 обучающихся второго курса, 69 студентов третьего курса, 58 обучающихся четвертого курса. Объемы выборки по курсам различаются в связи с отчислением студентов из-за отсутствия денежных средств для продолжения обучения и других причин (288 человеек). При повторном опросе через год потери выборки составили на втором курсе (бывшие первокурсники) - 7 студентов (8,3\%), на третьем (бывшие второкурсники) - 4 обучающихся (5,2 \%), на 
четвертом (бывшие третьекурсники) - 4 студента $(5,8 \%)$, на пятом (бывшие четверокурсники) 2 обучающихся $(3,4 \%)$ (271 человек).

В Алтайском государственном техническом университете им. И. И. Ползунова (АлтГМУ) в выборку были включены студенты гуманитарных специальностей. В первоначальную репрезентативную для АлтГТУ выборку попали 76 студентов первого курса, 70 обучающихся второго курса, 71 студент третьего курса, 68 обучающихся четвертого курса (285 человек). Потери выборки при повторном опросе составили 5,6 \%.

Согласно принятой концепции, творческий потенциал складывается из возможностей развития личности, обеспечиваемых комплексом выделенных качеств.

Начнем с готовности к риску, результаты опроса представлены в табл. 1 и 2.

Таблица 1

Распределение ответов студентов АЭЮИ на вопрос «Рискуете ли Вы получить плохую оценку, увлекшись перед экзаменом, зачетом, контрольной работой посторонним, но интересным предметом, работой, фильмом,

\begin{tabular}{|c|c|c|c|c|c|}
\hline \multirow{2}{*}{ Вариант ответа } & \multirow{2}{*}{$\begin{array}{l}\text { Год } \\
\text { опроса }\end{array}$} & \multicolumn{4}{|c|}{ Курс } \\
\hline & & $1-2-и ̆$ & $2-3-и ̆$ & 3-4-й & $4-5-и ̆$ \\
\hline \multirow[t]{2}{*}{ Да, это для меня норма } & 2015 & 4,3 & 4,5 & 13,7 & 12,9 \\
\hline & 2016 & 8,7 & 7,0 & 19,6 & 16,1 \\
\hline \multirow[t]{2}{*}{ Это бывает иногда } & 2015 & 47,8 & 58,2 & 37,3 & 29,0 \\
\hline & 2016 & 60,9 & 54,9 & 41,2 & 35,4 \\
\hline \multirow[t]{2}{*}{ Стараюсь не рисковать } & 2015 & 43,5 & 35,8 & 29,4 & 38,7 \\
\hline & 2016 & 30,4 & 33,8 & 27,4 & 29,0 \\
\hline Всегда готовлюсь & 2015 & 8,7 & 7,5 & 19,6 & 19,4 \\
\hline $\begin{array}{l}\text { заранее, откидывая } \\
\text { посторонние дела }\end{array}$ & 2016 & 4,3 & 4,3 & 11,8 & 19,4 \\
\hline
\end{tabular}

Распределение ответов студентов АлтГТУ на вопрос «Рискуете ли Вы получить плохую оценку, увлекиись перед экзаменом, зачетом, контрольной работой посторонним, но интересным предметом, работой, фильмом, книгой?», \%

\begin{tabular}{|c|c|c|c|c|c|}
\hline \multirow{2}{*}{ Вариант ответа } & \multirow{2}{*}{$\begin{array}{c}\text { Год } \\
\text { опроса }\end{array}$} & \multicolumn{4}{|c|}{ Курс } \\
\hline & & $1-2-и ̆$ & $2-3-\overline{-и ̆}$ & $3-4-и ̆$ & $4-5-\bar{и}$ \\
\hline \multirow[t]{2}{*}{ Да, это для меня норма } & 2015 & 0,0 & 8,0 & 13,0 & 25,0 \\
\hline & 2016 & 4,3 & 12,0 & 17,3 & 18,7 \\
\hline \multirow[t]{2}{*}{ Это бывает иногда } & 2015 & 39,1 & 28,0 & 43,5 & 62,5 \\
\hline & 2016 & 37,1 & 20,0 & 39,2 & 62,5 \\
\hline \multirow[t]{2}{*}{ Стараюсь не рисковать } & 2015 & 30,4 & 52,0 & 30,4 & 6,3 \\
\hline & 2016 & 28,2 & 48,0 & 37,7 & 12,6 \\
\hline Всегда готовлюсь & 2015 & 30,4 & 12,0 & 13,0 & 6,3 \\
\hline $\begin{array}{l}\text { заранее, откидывая } \\
\text { посторонние дела }\end{array}$ & 2016 & 30,4 & 16,0 & 8,7 & 6,3 \\
\hline
\end{tabular}

Анализ показывает, что удельный вес тех, для кого риск - норма, возрастает от первого курса к последнему. Результаты подтверждает и повторный вопрос.
С теми, кто рискует периодически, обратная картина. Если в частном вузе на первом - втором курсах этот показатель в среднем равен 51-55\%, то к старшим курсам сокращается уже до 30-32 \%. В АлтГТУ их число растет соответственно с 38 до $62 \%$.

В российской системе высшего образования высокие оценки академической успеваемости принято считать признаком успешного развития личности. Поэтому склонность к риску необходимо в первую очередь соотнести с реальной успеваемостью. Результаты ответов студентов на этот вопрос представлены в табл. 3 и 4.

Таблица 3

Распределение ответов студентов АЭЮИ на вопрос «Одинаковы ли Ваши успехи в учебе по всем дисииплинам?», \%

\begin{tabular}{|l|c|c|c|c|c|}
\hline \multirow{2}{*}{\multicolumn{1}{|c|}{ Вариант ответа }} & Год & \multicolumn{4}{|c|}{ Курс } \\
\cline { 3 - 6 } & опроса & $1-2-и ̆$ & $2-3-и ̆$ & $3-4-и ̆$ & $4-5-и ̆$ \\
\hline Одинаковы & 2015 & 4,3 & 4,4 & 4,1 & 9,7 \\
& 2016 & 4,8 & 6,8 & 6,4 & 8,8 \\
\hline Почти одинаковы & 2015 & 39,1 & 57,4 & 58,8 & 45,2 \\
& 2016 & 39,6 & 48,5 & 53,2 & 45,4 \\
\hline Очень не одинаковы & 2015 & 8,7 & 8,8 & 25,4 & 30,2 \\
& 2016 & 9,2 & 11,5 & 28,0 & 34,6 \\
\hline Могу по одним иметь & 2015 & 47,8 & 30,9 & 11,8 & 12,9 \\
пятерки, другие & 2016 & 46,4 & 33,2 & 12,4 & 11,2 \\
завалить & & & & & \\
\hline
\end{tabular}

Таблица 4

Распределение ответов студентов АлтГТУ на вопрос «Одинаковы ли Ваши успехи в учебе по всем дисичплинам?», \%

\begin{tabular}{|c|c|c|c|c|c|}
\hline \multirow[b]{2}{*}{ Вариант ответа } & \multirow{2}{*}{$\begin{array}{c}\text { Год } \\
\text { опроса }\end{array}$} & \multicolumn{4}{|c|}{ Курс } \\
\hline & & $1-2-и ̆$ & $2-3-и ̆$ & 3-4-й & 4-5-Й \\
\hline \multirow[t]{2}{*}{ Одинаковы } & 2015 & 4,3 & 4,0 & 4,3 & 6,3 \\
\hline & 2016 & 6,2 & 8,0 & 7,2 & 11,8 \\
\hline \multirow[t]{2}{*}{ Почти одинаковы } & 2015 & 69,6 & 64,0 & 73,9 & 52,5 \\
\hline & 2016 & 67,3 & 52,0 & 69,4 & 50,8 \\
\hline \multirow[t]{2}{*}{ Очень не одинаковы } & 2015 & 17,4 & 8,0 & 8,7 & 18,8 \\
\hline & 2016 & 14,9 & 12,0 & 8,8 & 12,6 \\
\hline Могу по одним иметь & 2015 & 8,7 & 24,0 & 13,0 & 22,4 \\
\hline пятерки, другие & 2016 & 12,0 & 28,0 & 14,6 & 24,8 \\
\hline
\end{tabular}

Из табл. 3 и 4 видно, что, несмотря на разницу между типами учебных заведений, у студентов много общего в распределении по вариантам и динамике. Достаточно значительна доля тех, кто имеет почти одинаковые оценки, правда, в АлтГТУ она к старшим курсам несколько снижается, а в АЭЮИ растет.

У студентов частного вуза прослеживается тенденция роста тех, кто имеет сильно неодинаковые оценки по мере углубления профессиональной специализации. На пятом курсе это уже более 30 \% опрошенных студентов. В государственном университете подобная тенденция не прослеживается: на 
последних курсах здесь доля избравших вариант очень неодинаковых оценок в два раза меньше.

Противоположные тенденции характерны и для последнего варианта ответа: в АЭЮИ - устойчивое падение, подтверждаемое повторным опросом, в АлтГТУ - заметный рост. Конечно, показатель в 22,4-24,8 \% - это не реальные двоечники, поскольку в пределах экзаменационной сессии (иногда позже) часть экзаменов можно пересдать на положительную оценку.

Согласно одной из гипотез исследования, неравномерность успехов в учебе может определяться сознательным выбором интересных и развивающих личность занятий, а отчасти импульсивностью как элементом темперамента, который развитию обычно не поддается. Импульсивность, видимо, будет коррелировать с неодинаковыми успехами в учебе. Признали себя импульсивными людьми в частном вузе 43,5 \% первокурсников, $39,7 \%$ второкурсников, 33,3 \% третьекурсников, 32,2 \% четверокурсников. Их доля снижается в среднем на 2-3 \% при повторном опросе.

В пределах $20 \%$ доля тех, кто не признал себя импульсивной личностью, остальные затруднились в ответе или выбрали нейтральный ответ «иногда». В АлтГТУ отметили импульсивность в своем характере соответственно 52,2; 32,0; 21,7 и $37,5 \%$.

Определить закономерность, существенность этих связей помогают другие вопросы анкеты о структуре интересов, предпочтениях в сложных ситуациях выбора между требованиями учебной дисциплины и интересным творческим делом. Результаты опроса по этим вопросам представлены в табл. 5-8.

Сравнение результатов анкетирования показывает, что значительно большая часть студентов частного вуза, чем государственного, проявляет интерес к посещению театров, выставок, концертов.

Распределение ответов студентов АЭЮИ на вопрос «На что Вы тратите свое свободное

\begin{tabular}{|c|c|c|c|c|c|}
\hline \multirow[b]{2}{*}{ Вариант ответа } & \multirow{2}{*}{$\begin{array}{c}\text { Год } \\
\text { опроса }\end{array}$} & \multicolumn{4}{|c|}{ Курс } \\
\hline & & $1-2-и ̆$ & $2-3-\breve{и ̆}$ & $3-4-\breve{и ̆}$ & $4-5-$ й \\
\hline \multirow[t]{2}{*}{ Общение с друзьями } & 2015 & 60,9 & 76,5 & 64,7 & 51,6 \\
\hline & 2016 & 60,2 & 68,4 & 60,4 & 44,2 \\
\hline \multirow{2}{*}{$\begin{array}{l}\text { Посещение театров, } \\
\text { выставок и т. д. }\end{array}$} & 2015 & 0,0 & 7,4 & 11,8 & 22,6 \\
\hline & 2016 & 2,3 & 10,2 & 14,6 & 20,4 \\
\hline \multirow[t]{2}{*}{ Провожу у телевизора } & 2015 & 8,7 & 20,6 & 13,7 & 22,6 \\
\hline & 2016 & 10,8 & 16,8 & 20,4 & 24,2 \\
\hline \multirow[t]{2}{*}{ Занимаюсь спортом } & 2015 & 17,4 & 26,5 & 19,6 & 22,6 \\
\hline & 2016 & 18,2 & 22,7 & 18,8 & 27,2 \\
\hline \multirow[t]{2}{*}{ Что-то еще } & 2015 & 8,7 & 7,4 & 7,8 & 16,1 \\
\hline & 2016 & 7,7 & 6,2 & 10,4 & 12,8 \\
\hline \multirow{2}{*}{$\begin{array}{l}\text { У меня нет свободного } \\
\text { времени }\end{array}$} & 2015 & 30,4 & 23,5 & 29,4 & 29,0 \\
\hline & 2016 & 28,3 & 25,6 & 22,6 & 27,2 \\
\hline
\end{tabular}

Таблица 6

Распределение ответов студентов АлтГТУ на вопрос «На что Вы тратите свое свободное время?», \%

\begin{tabular}{|c|c|c|c|c|c|}
\hline \multirow[b]{2}{*}{ Вариант ответа } & \multirow{2}{*}{$\begin{array}{c}\text { Год } \\
\text { опроса }\end{array}$} & \multicolumn{4}{|c|}{ Курс } \\
\hline & & 1-2-й & $2-3-\bar{и}$ & 3-4-й & 4-5-й \\
\hline \multirow[t]{2}{*}{ Общение с друзьями } & 2015 & 60,9 & 72,0 & 73,9 & 75,0 \\
\hline & 2016 & 64,0 & 68,3 & 71,4 & 68,5 \\
\hline \multirow{2}{*}{$\begin{array}{l}\text { Посещение театров, } \\
\text { выставок и т. д. }\end{array}$} & 2015 & 4,3 & 12,0 & 0,0 & 12,5 \\
\hline & 2016 & 6,0 & 10,8 & 3,1 & 10,0 \\
\hline \multirow[t]{2}{*}{ Провожу у телевизора } & 2015 & 8,7 & 16,0 & 30,4 & 25,0 \\
\hline & 2016 & 10,0 & 22,2 & 28,6 & 22,0 \\
\hline \multirow[t]{2}{*}{ Занимаюсь спортом } & 2015 & 8,7 & 8,0 & 21,7 & 31,3 \\
\hline & 2016 & 8,0 & 8,4 & 15,9 & 26,5 \\
\hline \multirow[t]{2}{*}{ पто-то еще } & 2015 & 17,4 & 24,0 & 21,7 & 37,5 \\
\hline & 2016 & 16,0 & 21,8 & 18,2 & 25,0 \\
\hline \multirow{2}{*}{$\begin{array}{l}\text { У меня нет свободного } \\
\text { времени }\end{array}$} & 2015 & 17,4 & 12,0 & 13,0 & 6,3 \\
\hline & 2016 & 16,0 & 10,8 & 11,4 & 8,0 \\
\hline
\end{tabular}

$20 \%$ опрошенных студентов частного вуза занимается спортом. Этот показатель достаточно стабилен и подтверждается повторным опросом 2016 г. У студентов государственного университета число назвавших занятие спортом также увеличивается к старшим курсам, но при этом заметно - в среднем на $6 \%$ - падает на последнем курсе.

На всех курсах частного вуза около $25 \%$ опрошенных студентов отмечают нехватку свободного времени, в то время как в АлтГТУ этот показатель непрерывно падает, достигая к последним курсам 6-8\%. Для проверки в анкету был включен один контрольный вопрос на эту тему (табл. 7 и 8).

Таблица 7

Распределение ответов студентов АЭЮИ на вопрос «На что Вам не хватает времени?», \%

\begin{tabular}{|c|c|c|c|c|c|}
\hline \multirow{2}{*}{ Вариант ответа } & \multirow{2}{*}{\begin{tabular}{|c|} 
Год \\
опроса
\end{tabular}} & \multicolumn{4}{|c|}{ Курс } \\
\hline & & $1-2-\bar{и}$ & $2-3-\overline{и ̆}$ & $3-4-и ̆$ & $4-5-\breve{и}$ \\
\hline \multirow{2}{*}{$\begin{array}{l}\text { На подготовку домаш- } \\
\text { них заданий }\end{array}$} & 2015 & 43,5 & 13,2 & 39,2 & 45,2 \\
\hline & 2016 & 27,2 & 22,5 & 34,8 & 28,6 \\
\hline \multirow[t]{2}{*}{ На развлечения } & 2015 & 13,0 & 26,5 & 19,6 & 6,5 \\
\hline & 2016 & 20,4 & 20,0 & 15,3 & 8,9 \\
\hline \multirow[t]{2}{*}{ На занятия спортом } & 2015 & 13,0 & 32,4 & 37,3 & 29,0 \\
\hline & 2016 & 22,6 & 28,5 & 29.9 & 28,6 \\
\hline \multirow{2}{*}{$\begin{array}{l}\text { На занятие интересным, } \\
\text { творческим делом }\end{array}$} & 2015 & 4,3 & 8,8 & 27,5 & 16,1 \\
\hline & 2016 & 5,8 & 12,5 & 19,6 & 18,4 \\
\hline \multirow{2}{*}{$\begin{array}{l}\text { На чтение художествен- } \\
\text { ной литературы }\end{array}$} & 2015 & 21,7 & 25,0 & 25,5 & 16,1 \\
\hline & 2016 & 19,3 & 22,5 & 19,6 & 18,4 \\
\hline \multirow{2}{*}{$\begin{array}{l}\text { На работу в целях } \\
\text { заработка }\end{array}$} & 2015 & 39,1 & 39,7 & 47,1 & 61,3 \\
\hline & 2016 & 36,2 & 35,0 & 34,8 & 35,1 \\
\hline \multirow{2}{*}{ Другой вариант } & 2015 & 0,0 & 11,8 & 2,0 & 0,0 \\
\hline & 2016 & 1,4 & 12,5 & 6,4 & 2,2 \\
\hline
\end{tabular}

Результаты ответов на вопросы табл. 7 и 8 представляют интерес не сами по себе, а в сравнении с ответами на предшествующие задания. Они не повторяют и не тиражируют друг друга. Например, при сопоставлении вариантов ответа на вопрос «У меня нет свободного времени» и с «нехваткой времени на подготовку домашних заданий» выяснилось, что у студентов АЭЮИ (по всему массиву) 
существует слабая положительная корреляция $(r=0,26)$, а у студентов АлтГТУ она практически отсутствует $(r=0,1)$. Значит, респонденты обоих вузов признают необходимость подготовки домашних заданий, но не торопятся тратить на него свое свободное время.

Таблица 8

Распределение ответов студентов АлтГТУ на вопрос «На что Вам не хватает времени?», \%

\begin{tabular}{|c|c|c|c|c|c|}
\hline \multirow[b]{2}{*}{ Вариант ответа } & \multirow{2}{*}{$\begin{array}{c}\text { Год } \\
\text { опроса }\end{array}$} & \multicolumn{4}{|c|}{ Курс } \\
\hline & & $1-2-$ й & 2-3-й & 3-4-й & 4-5-й \\
\hline \multirow{2}{*}{$\begin{array}{l}\text { На подготовку домаш- } \\
\text { них заданий }\end{array}$} & 2015 & 17,4 & 32,0 & 39,1 & 50,0 \\
\hline & 2016 & 16,8 & 30,0 & 42,7 & 36,2 \\
\hline \multirow[t]{2}{*}{ На развлечения } & 2015 & 47,8 & 20,0 & 8,7 & 12,5 \\
\hline & 2016 & 32,2 & 16,0 & 8,2 & 12,3 \\
\hline \multirow[t]{2}{*}{ На занятия спортом } & 2015 & 91,7 & 28,0 & 30,4 & 18,8 \\
\hline & 2016 & 92,4 & 30,0 & 30,5 & 32,3 \\
\hline \multirow{2}{*}{$\begin{array}{l}\text { На занятие интересным, } \\
\text { творческим делом }\end{array}$} & 2015 & 8,7 & 16,0 & 8,7 & 12,5 \\
\hline & 2016 & 10,6 & 8,0 & 8,2 & 12,3 \\
\hline \multirow{2}{*}{$\begin{array}{l}\text { На чтение художествен- } \\
\text { ной литературы }\end{array}$} & 2015 & 26,4 & 36,0 & 4,3 & 12,5 \\
\hline & 2016 & 22,4 & 30,0 & 30,5 & 16,7 \\
\hline \multirow{2}{*}{$\begin{array}{l}\text { На работу в целях } \\
\text { заработка }\end{array}$} & 2015 & 8,7 & 16,0 & 30,4 & 31,3 \\
\hline & 2016 & 10,6 & 18,0 & 18,9 & 32,3 \\
\hline \multirow[t]{2}{*}{ Другой вариант } & 2015 & 0,0 & 16,0 & 4,3 & 6,3 \\
\hline & 2016 & 2,1 & 18,0 & 8,2 & 6,2 \\
\hline
\end{tabular}

Расчеты показывают, что существует зависимость между неодинаковыми успехами по разным дисциплинам и работой в целях заработка $(r=0,47)$, а нехватка времени на интересные творческие дела слабо коррелирует с данным вариантом ответа табл. 3 и 4 в обоих вузах.

Пока речь шла о свободном времени, об оценке поведения студентов вне учебного процесса. Основной целью является проверка влияния типа учебного заведения на развитие творческого потенциала.

Прежде всего необходимо отметить приоритетность гуманитарных наук, которые, по мнению студентов, больше, чем остальные, развивают творческое мышление. Даже менеджеры и экономисты, изучающие достаточно математических и технологических дисциплин, отдали предпочтение (78-85 \%) гуманитарному знанию как источнику творческих импульсов.

Как ведут себя студенты, сталкиваясь с интересными, требующими творческого воображения (по их мнению) и рутинными дисциплинами в условиях дефицита времени? Ответ на этот вопрос дает содержание табл. 9 и 10.

Из табл. 11 и 12 видно, что среди студентов АлтГТУ к старшим курсам стремительно растет доля тех, кому фактически учеба безразлична, в частном вузе доля избравших первый вариант ответа стабильна и не превышает 4-5\%. Достаточно стабильна группа студентов АЭЮИ, равномерно распределяющих время между всеми предметами и, согласно гипотезе авторов, слабо ориентированная на творчество.
Таблица 9

Распределение ответов студентов АЭЮИ на вопрос «Если программой обучения предусмотрены интересные и неинтересные дисииплины, то как Bы поступаете?», \%

\begin{tabular}{|l|c|c|c|c|c|}
\hline \multirow{2}{*}{\multicolumn{1}{|c|}{ Вариант ответа }} & Год & \multicolumn{4}{|c|}{ Курс } \\
\cline { 3 - 7 } & опроса & $1-2-и ̆$ & $2-3-и ̆$ & $3-4-и ̆$ & $4-5-и ̆$ \\
\hline Мои интересы лежат & 2015 & 8,7 & 1,5 & 5,9 & 3,2 \\
вне учебы, поэтому & 2016 & 6,5 & 3,0 & 4,2 & 4,2 \\
я не отдаю предпочте- & & & & & \\
ния отдельным & & & & & \\
дисциплинам & & & & & \\
\hline Равномерно распреде- & 2015 & 52,3 & 67,6 & 64,7 & 54,8 \\
ляю время, чтобы & 2016 & 54,5 & 64,8 & 60,8 & 46,2 \\
успевать по всем & & & & & \\
дисциплинам & & & & & \\
\hline Занимаюсь в основном & 2015 & 42,5 & 27,9 & 33,3 & 48,6 \\
теми предметами, & 2016 & 43,6 & 23,2 & 35,0 & 45,4 \\
которые мне инте- & & & & & \\
ресны & & & & & \\
\hline Другой вариант & 2015 & 0,0 & 11,8 & 0,0 & 3,2 \\
& 2016 & 6,5 & 9,0 & 0,0 & 4,2 \\
\hline
\end{tabular}

Таблица 10

Распределение ответов студентов АлтГТУ на вопрос «Если программой обучения предусмотрены интересные и неинтересные дисииилины, то как Вы поступаете?», \%

\begin{tabular}{|c|c|c|c|c|c|}
\hline \multirow{2}{*}{ Вариант ответа } & \multirow{2}{*}{$\begin{array}{c}\text { Год } \\
\text { опроса }\end{array}$} & \multicolumn{4}{|c|}{ Курс } \\
\hline & & $1-2-и ̆$ & $2-3-\breve{и ̆}$ & 3-4-й & 4-5-й \\
\hline $\begin{array}{l}\text { Мои интересы лежат вне } \\
\text { учебы, поэтому я не } \\
\text { отдаю предпочтения } \\
\text { отдельным дисциплинам }\end{array}$ & $\begin{array}{l}2015 \\
2016\end{array}$ & $\begin{array}{l}0,0 \\
6,3\end{array}$ & $\begin{array}{l}0,0 \\
4,0\end{array}$ & $\begin{array}{l}17,4 \\
15,4\end{array}$ & $\begin{array}{l}31,1 \\
37,4\end{array}$ \\
\hline $\begin{array}{l}\text { Равномерно распределяю } \\
\text { время, чтобы успевать по } \\
\text { всем дисциплинам }\end{array}$ & $\begin{array}{l}2015 \\
2016\end{array}$ & $\begin{array}{l}73,9 \\
50,0\end{array}$ & $\begin{array}{l}56,0 \\
60,0\end{array}$ & $\begin{array}{l}65,2 \\
54,2\end{array}$ & $\begin{array}{l}37,5 \\
25,2\end{array}$ \\
\hline $\begin{array}{l}\text { Занимаюсь в основном } \\
\text { теми предметами, } \\
\text { которые мне интересны }\end{array}$ & $\begin{array}{l}2015 \\
2016\end{array}$ & $\begin{array}{l}21,7 \\
37,4\end{array}$ & $\begin{array}{l}40,0 \\
28,0\end{array}$ & $\begin{array}{l}21,7 \\
30,4\end{array}$ & $\begin{array}{l}31,3 \\
37,4\end{array}$ \\
\hline Другой вариант & $\begin{array}{l}2015 \\
2016\end{array}$ & $\begin{array}{l}4,3 \\
6,3\end{array}$ & $\begin{array}{l}8,0 \\
8,0\end{array}$ & $\begin{array}{l}0,0 \\
0,0\end{array}$ & $\begin{array}{l}0,0 \\
0,0\end{array}$ \\
\hline
\end{tabular}

В среднем более 30 \% обучающихся АлтГТУ и около $40 \%$ студентов частного вуза в ходе учебного процесса уделяют внимание в основном интересующим их предметам. Повторный опрос не выявил какой-либо статистически существенной динамики по этому варианту ответа. Расчеты показывают знаяительную положительную корреляцию между данным признаком и интересом к учебной дисциплине в зависимости от личности преподавателя $(r=0,57)$, и в то же время отсутствие корреляции с нехваткой времени на интересные творческие дела (табл. 7 и 8 ).

Наконец, анкета предлагала студентам своеобразную самооценку, включавшую и творческие качества. 
Оценивая результаты опроса, представленные в табл. 11 и 12, необходимо иметь в виду, что это проекция личностных качеств студента на отношения с друзьями и коллегами. Для дружбы творческий потенциал личности может и не обладать той значимостью, которую имеет в области учебы и работы.

Наиболее явно идентификация с творчеством видна на примере «способности генерировать новые идеи, придумывать что-то интересное».

К сожалению, в обоих вузах число студентов, отметивших значимость данного качества в общении с друзьями и коллегами, снижается к старшим курсам. Тенденция отчетливо подтверждается и повторным опросом, а значит, не случайна. Справедливости ради надо признать, что у студентов АЭЮИ показатель выше.

Слабо выражено в дружеском общении такое качество, как любознательность, причем у студентов АлтГТУ ее значимость значительно падает на старших курсах. Одинаковы и относительно стабильны на разных курсах оценки таких качеств, как оптимизм и смелость. В частном вузе смелых примерно в полтора раза больше.

Таблица 11

Распределение ответов студентов АЭЮИ на вопрос «Как Вы считаете, за какие из перечисленных качеств Вас иенят ваши друзья и коллеги?», \%

\begin{tabular}{|l|c|c|c|c|c|}
\hline \multirow{2}{*}{ Вариант ответа } & Год & \multicolumn{4}{|c|}{ Курс } \\
\cline { 3 - 6 } & опроса & $1-2-и ̆$ & $2-3-и ̆$ & $3-4-и ̆$ & $4-5-и ̆$ \\
\hline Трудолюбие & 2015 & 0,0 & 23,5 & 21,6 & 12,9 \\
& 2016 & 4,3 & 24,2 & 22,9 & 13,8 \\
\hline Отзывчивость & 2015 & 56,5 & 57,4 & 51,0 & 45,2 \\
& 2016 & 56,8 & 59,1 & 54,2 & 48,3 \\
\hline Организаторские & 2015 & 13,0 & 23,5 & 21,6 & 16,1 \\
способности & 2016 & 17,4 & 24,2 & 22,9 & 17,2 \\
\hline Юмор & 2015 & 60,9 & 48,5 & 43,1 & 51,6 \\
& 2016 & 52,2 & 50,0 & 45,8 & 55,2 \\
\hline Любознательность & 2015 & 13,0 & 22,1 & 25,5 & 6,5 \\
& 2016 & 8,7 & 15,2 & 16,7 & 20,7 \\
\hline Дисциплинированность & 2015 & 21,7 & 19,1 & 19,6 & 25,8 \\
& 2016 & 17,4 & 19,7 & 20,8 & 27,6 \\
\hline Способность генериро- & 2015 & 34,8 & 33,8 & 27,5 & 24,7 \\
вать новые идеи, & 2016 & 30,4 & 30,3 & 18,8 & 20,7 \\
придумывать что-то & & & & & \\
интересное & & & & & \\
\hline Справедливость & 2015 & 39,1 & 33,8 & 37,3 & 45,2 \\
& 2016 & 43,2 & 34,8 & 39,6 & 48,3 \\
\hline Упорство в достижении & 2015 & 34,8 & 23,4 & 19,6 & 29,0 \\
цели & 2016 & 30,4 & 30,3 & 20,8 & 27,6 \\
\hline Осторожность, & 2015 & 17,4 & 29,4 & 17,6 & 25,8 \\
уравновешенность & 2016 & 21,7 & 30,3 & 18,8 & 37,9 \\
\hline Оптимизм & 2015 & 30,4 & 27,9 & 25,5 & 45,2 \\
& 2016 & 30,4 & 28,8 & 27,1 & 48,3 \\
\hline Смелость & 2015 & 21,7 & 29,4 & 27,5 & 32,3 \\
& 2016 & 26,1 & 24,2 & 18,8 & 24,1 \\
\hline доброжелательность & 2015 & 52,2 & 54,4 & 54,9 & 64,5 \\
& 2016 & 60,9 & 56,1 & 58,3 & 69,0 \\
\hline
\end{tabular}

Таблица 12

Распределение ответов студентов АлтГТУ на вопрос «Как Вы считаете, за какие из перечисленных качеств Вас иенят ваши друзья и коллеги?», \%

\begin{tabular}{|c|c|c|c|c|c|}
\hline \multirow{2}{*}{ Вариант ответа } & \multirow{2}{*}{$\begin{array}{c}\text { Год } \\
\text { опроса }\end{array}$} & \multicolumn{4}{|c|}{ Курс } \\
\hline & & $1-2-$ й & $2-3$-й & $3-4-и ̆$ & $4-5-\breve{и ̆}$ \\
\hline \multirow[t]{2}{*}{ Трудолюбие } & 2015 & 26,1 & 8,0 & 17,4 & 18,8 \\
\hline & 2016 & 16,3 & 14,6 & 14,8 & 15,5 \\
\hline \multirow[t]{2}{*}{ Отзывчивость } & 2015 & 65,2 & 52,0 & 52,2 & 56,3 \\
\hline & 2016 & 45,5 & 47,1 & 66,9 & 62,0 \\
\hline \multirow{2}{*}{$\begin{array}{l}\text { Организаторские } \\
\text { способности }\end{array}$} & 2015 & 8,7 & 16,0 & 17,4 & 6,3 \\
\hline & 2016 & 6,5 & 15,7 & 17,3 & 8,6 \\
\hline \multirow[t]{2}{*}{ Юмор } & 2015 & 65,2 & 64,0 & 13,0 & 43,8 \\
\hline & 2016 & 56,5 & 68,8 & 14,8 & 46,5 \\
\hline \multirow[t]{2}{*}{ Любознательность } & 2015 & 21,7 & 12,0 & 13,0 & 6,3 \\
\hline & 2016 & 22,8 & 14,6 & 14,8 & 5,2 \\
\hline \multirow[t]{2}{*}{ Дисциплинированность } & 2015 & 13,0 & 20,6 & 13,0 & 31.3 \\
\hline & 2016 & 14,1 & 11,2 & 17,3 & 15,5 \\
\hline \multirow{2}{*}{$\begin{array}{l}\text { Способность генериро- } \\
\text { вать новые идеи, } \\
\text { придумывать что-то } \\
\text { интересное }\end{array}$} & 2015 & 26,1 & 24,0 & 17,4 & 12.5 \\
\hline & 2016 & 22,8 & 15,7 & 17.3 & 15.5 \\
\hline \multirow[t]{2}{*}{ Справедливость } & 2015 & 21,7 & 12,0 & 30,4 & 37,5 \\
\hline & 2016 & 22,8 & 11,2 & 26,1 & 31,0 \\
\hline \multirow{2}{*}{$\begin{array}{l}\text { Упорство в достижении } \\
\text { цели }\end{array}$} & 2015 & 26,1 & 16,0 & 17,4 & 12.5 \\
\hline & 2016 & 22,8 & 15,7 & 17,3 & 10,3 \\
\hline \multirow{2}{*}{$\begin{array}{l}\text { Осторожность, уравно- } \\
\text { вешенность }\end{array}$} & 2015 & 30,4 & 21,0 & 34,8 & 31,3 \\
\hline & 2016 & 39,0 & 15,7 & 34,6 & 31,0 \\
\hline \multirow[t]{2}{*}{ Оптимизм } & 2015 & 26,1 & 40,0 & 34,8 & 31,3 \\
\hline & 2016 & 22,8 & 36,0 & 14,8 & 31,0 \\
\hline \multirow[t]{2}{*}{ Смелость } & 2015 & 13,0 & 12,0 & 17,4 & 18,8 \\
\hline & 2016 & 16,3 & 11,2 & 17,3 & 15,5 \\
\hline \multirow[t]{2}{*}{ Доброжелательность } & 2015 & 56,5 & 56,0 & 60,9 & 56,3 \\
\hline & 2016 & 65,2 & 62,8 & 59,2 & 62,0 \\
\hline
\end{tabular}

Положительная корреляция существует между склонностью к риску (см. табл. 1 и 2) и смелостью как качеством, ценимым друзьями $(r=0,63)$, неодинаковостью успехов в различных дисциплинах (см. табл. 3 и 4) и любознательностью $(r=0,39)$, между склонностью к риску и способностью генерировать идеи $(r=0,40)$, между предпочтением интересных дел в досуговых занятиях и любознательностью $(r=0,36)$. В целом большинством из качеств, включенных в творческий потенциал личности студента, обладают примерно 25-30 \% студентов обоих вузов. Одни качества сильнее выражены у студентов АЭЮИ, другие - у студентов АлтГТУ. Это подтверждают и результаты тестирования, представленные в табл. 13 и 14.

Проведенный сопоставимый анализ результатов тестирования студентов обоих образовательных организаций показывает, что существенные различия в уровне творческого потенциала отсутствуют. Однако у студентов АлтГТУ прослеживается тенденция снижения показателя творческого потенциала к старшим курсам. 


\begin{tabular}{|c|c|c|c|c|}
\hline \multicolumn{3}{|c|}{$\begin{array}{l}\text { Результаты тестирования творческого } \\
\text { потенциала студентов АЭЮИ, балл }\end{array}$} & \multicolumn{2}{|c|}{$\begin{array}{l}\text { Таблица } 13 \\
\text { иворческого } \\
\text { ЮИ, балл }\end{array}$} \\
\hline \multirow[b]{2}{*}{ Год опроса } & \multicolumn{4}{|c|}{ Курс } \\
\hline & 1-2-й & $2-3$ й & 3-4-й & 4-5-й \\
\hline 2015 & 31 & 34 & 27 & 34 \\
\hline 2016 & 36 & 35 & 32 & 31 \\
\hline
\end{tabular}

Таблица 14

Результаты тестирования творческого потенциала студентов АлтГТУ, балл

\begin{tabular}{|c|c|c|c|c|}
\hline \multirow[b]{2}{*}{ Год опроса } & \multicolumn{4}{|c|}{ Курс } \\
\hline & $1-2-и ̆$ & $2-3-и ̆$ & $3-4-и ̆$ & $4-5-и ̆$ \\
\hline 2015 & 37 & 36 & 23 & 28 \\
\hline 2016 & 32 & 35 & 26 & 27 \\
\hline
\end{tabular}

В этом случае треть выявленных ранее студентов действительно получила более высокие баллы в обоих вузах: средние значения колеблются в пределах 38-45 баллов. В АЭЮИ лишь $6 \%$ обучающихся первого курса, 4 \% студентов второго курса, $6 \%$ обучающихся третьего курса и $6 \%$ студентов четвертого курса набрали более 45 баллов. В государственном университете соответственно 5, 6, 3, $2 \%$.

По итогам сравнительного исследования творческого потенциала личности студента можно сделать следующие выводы.

1. Тип образовательной организации не влияет существенно на удельный вес студентов, обладающих творческим потенциалом.

2. Опрос студентов гуманитарных специальностей разных курсов частного института и государ- ственного университета, а также повторный опрос их в следующем году с небольшими потерями выборки показывает, что число студентов с проанализированными в процессе анкетирования критериями творческого потенциала варьирует в пределах 25-35 \%. Всеми необходимыми качествами обладают в обоих образовательных организациях не более $10-12 \%$ опрошенных студентов.

У $50 \%$ опрошенных обучающихся данные качества выражены слабо или асимметрично. Пятая часть опрошенных студентов ориентирована на нетворческий учебный процесс в вузе и профессиональную карьеру, проявляет явный конформизм.

3. Оснований для вывода о развитии творческого потенциала личности студентов в целом недостаточно, о чем указывают удельные веса творческих личностей на разных курсах. Причины авторы видят в том, что, во-первых, основа для такого развития закладывается раньше, до поступления в высшее учебное заведение, во-вторых, часть студентов, обладающих творческим потенциалом, выбывает из вуза по разным причинам: невозможность дальнейшего финансирования образования, конфликты с преподавателями и др.

4. В частной образовательной организации высшего образования, несмотря на действие различных обстоятельств, доля студентов, обладающих творческим потенциалом, остается достаточно стабильной, а в государственном университете действует тенденция снижения числа таких обучающихся.

\section{Список литературы}

1. Давыдова И. В. Развитие творческого потенциала студентов педвуза в процессе их совместной учебной деятельности: автореф. дис. ... канд. пед. наук. СПб., 2009. 24 с.

2. Медведева Л. Д. О подготовке специалистов экономического профиля в условиях глобализации // Вестн. Томского гос. пед. ун-та (TSPU Bulletin). 2009. Вып. 2 (80). С. 76-79.

3. Малахова О. Ю. Роль рефлексивно-образовательной среды в профессионально-личностном самоопределении студента вуза // Образование и общество. 2015. № 1 (90). С. 87-91.

4. Мясникова Т. В. Мотивация обучения студентов посредством моделирования // Молодой ученый. 2014. № 18 (77). С. $614-617$.

5. Андреев В. И. Педагогика высшей школы. Казань: Центр инновационных технологий, 2005. 500 с.

6. Хуторской А. В. Ключевые компетенции как компонент личностно ориентированного образования // Народное образование. 2003 . № 2. C. 58-64.

7. Блинов В. И., Батрова О. Ф., Есенина Е. Ю., Факторович А. А. Современные подходы к оцениванию квалификаций // Высшее образование в России. 2013. № 5. С. 100-106.

8. Панов В. И. Роль гуманитарного образования в профессиональной подготовке технических специалистов // Человек - образование профессия: материалы V Междунар. науч.-практ. конф. (6-8 июля, 2009 г.) / под ред. Л. М. Митиной. М.: ПИ РАО, МГППУ, 2009. C. 34-38.

9. Сазонов Б. А. Индивидуально ориентированная организация учебного процесса как условие модернизации высшего образования // Высшее образование в России. 2011. № 4. С. 10-24.

10. Поздеева С. И., Обсков А. В. Диагностика функционально-смыслового содержания совместной деятельности и позиции преподавателя на учебном занятии по иностранному языку в техническом вузе // Вестн. Томского гос. пед. ун-та (TSPU Bulletin). 2017. Bып. 1 (178). C. 119-125. DOI: $10.23951 / 1609-624 X-2017-1-119-125$. 
Степанов Виктор Иванович, кандидат педагогических наук, Алтайский экономико-юридический институт (пр. Красноармейский, 108, Барнаул, Россия, 656015).

E-mail: svi_2@mail.ru

Материал поступил в редакциию 28.02.2018.

DOI 10.23951/1609-624X-2018-5-166-174

CREATIVE POTENTIAL DEVELOPMENT OF INDIVIDUAL STUDENTS IN THE LEARNING PROCESS

\section{I. Stepanov}

Altai Economics and Law Institute, Barnaul, Russian Federation

The article reflects the ideas of development of creative potential of students' personality in the process of their professional training. The state of the studied problem in pedagogical theory and practice is studied, perspective approaches to its solution are defined, the conceptual apparatus of research is specified. The state of the problem of students' creative potential is analyzed. In the process of its development, we have identified the stages in the logic of the main trends. Ideas about creative potential of students' personality are developed. The aspects of development of creative potential of personality of students are considered, pedagogical conditions of its formation, creation of the creative environment, inducements of reflexive activity, dialogization of educational process are allocated. There was conducted the survey and testing of students of Altai State Technical University and Altai Economics and Law Institute. The results of the study of the creative potential of students in the process of training in public and private universities are presented. These surveys and tests allowed the author to conclude that the type of educational institution does not significantly affect the proportion of students with explicit and empirically fixed creative potential. A survey of students of different courses, as well as a repeated survey of the same panel with minor sample losses showed that the number of students with the author's analyzed criteria of creative potential varies between 25-35 percent. No more than 10-12 percent of respondents in both universities have all the necessary qualities. Half of respondents express these qualities poorly or asymmetrically, the fifth part of the surveyed students focused on noncreative study and professional career, shows obvious conformism. The grounds for the conclusion about the development of the creative potential of students in General is not enough, as evidenced by the specific weight of creative personalities in different courses. The author sees the reasons in the fact that, firstly, the basis for such development is laid earlier, before entering the University, and secondly, some students with creative potential are eliminated from the educational process for various reasons: lack of money for education, conflicts with the administration, etc. in a private University, despite the action of various circumstances, the proportion of students with creative potential remains quite stable, and in a state University there is a tendency to reduce the number of such students.

Key words: creative potential of students personality, risk tendency, conscious choice of interesting and developing activities.

\section{References}

1. Davydova I. V. Razvitiye tvorcheskogo potentsiala studentov pedvuza v protsesse ikh sovmestnoy uchebnoy deyatel'nosti. Avtoref. dis. kand. ped. nauk [Development of creative potential of students of teacher training University in the process of their cocurricular activities. Abstract of thesis of cand. of ped. sci.]. Saint Petersburg, 2009. 24 p. (in Russian).

2. Medvedeva L. D. O podgotovke spetsialistov ekonomicheskogo profilya v usloviyakh globalizatsii [About training of specialists of the economic profile in the conditions of globalization]. Vestnik Tomskogo gosudarstvennogo pedagogicheskogo universiteta - TSPU Bulletin, 2009, vol. 2 (80), pp. 76-79 (in Russian).

3. Malakhova O. Yu. Rol' refleksivno-obrazovatel'noy sredy v professional'no-lichnostnom samoopredelenii studenta vuza [The Role of refl exiveeducational environment in professional and personal self-determination of a student]. Obrazovaniye i obshchestvo - Education and Society, 2015, no. 1 (90), pp. 87-91 (in Russian).

4. Myasnikova T. V. Motivatsya obucheniya studentov posredstvom modelirovaniya [Motivation of students learning through modeling]. Molodoy uchenyy, 2014, no. 18 (77), pp. 614-617 (in Russian).

5. Andreev V. I. Pedagogika vysshey shkoly [Pedagogy of higher education]. Kazan, Tsentr innovatsionnykh tekhnologiy Publ., 2005. 500 p. (in Russian).

6. Khutorskoy A. V. Klyuchevyye kompetentsii kak component lichnostno oriyentirovannogo obrazovaniya [Key competencies as a component of learner-centered approach]. Narodnoye obrazovaniye - National Education, 2003, no. 2, pp. 58-64 (in Russian).

7. Blinov V. I., Batrova O. F., Esenina E. Yu., Faktorovich A. A. Sovremennyye podkhody k otsenivaniyu kvalifikatsiy [Modern approaches to qualification assessment]. Vyssheye obrazovaniye v Rossii - Higher Education in Russia, 2013, no. 5, pp. 100-106 (in Russian). 
8. Panov V. I. Rol' gumanitarnogo obrazovaniya v professional'noy podgotovke tekhnicheskikh spetsialistov [The role of humanitarian education in professional training of technical specialists]. Chelovek - obrazovaniye - professiya: materialy V Mezhdunarodnoy nauchno-prakticheskoy konferentsii (6-8 iyulya 2009 g.) [Man - education - profession: the materials of the 5 international sci.-pract. conf. (6-8 July 2009)]. Moscow, MSPU Publ., 2009, pp. 34-38 (in Russian).

9. Sazonov B. A. Individual'no oriyentirovannaya organizatsiya uchebnogo protsessa kak usloviye vysshego obrazovaniya [Individual-oriented organization of educational process as a condition of modernization of higher education]. Vyssheye obrazovaniye $v$ Rossii - Higher Education in Russia, 2011, no. 4, pp. 10-24 (in Russian).

10. Pozdeeva S. I., Obskov A.V. Diagnostika funktsional'no-smyslovogo soderzhaniya sovmestnoy deyatel'nosti i pozitsii prepodavatelya na uchebnom zanyatii po inostrannomu yazyku v tekhnicheskom vuze [Functional Semantic Diagnostics of Joint Activities and Teaching Positions at Technical University]. Vestnik Tomskogo gosudarstvennogo pedagogicheskogo universiteta - TSPU Bulletin, 2017, vol. 1 (178), pp. 119-125. DOI: 10.23951/1609-624X-2017-1-119-125 (in Russian).

Stepanov V. I., Altai Economics and Law Institute (pr. Krasnoarmeyskiy, 108, Barnaul, Russian Federation, 656015). E-mail: svi_2@mail.ru 